\title{
In-vitro and In-vivo effects of Cu-Melo Seed 'trypsinseed'trypsin Inhibitor on Angiogenesis and Tumor Characteristics in Balb-c Mice With Breast Cancer
}

\section{Shahla Rezaei}

Shiraz University of Medical Sciences

Negar Azarpira

Shiraz University of Medical Sciences

\section{Farhad Koohpeyma}

Shiraz University of Medical Sciences

\section{Reza Yousefi}

Shiraz University

\section{Mojdeh Heidari}

Shiraz University of Medical Sciences

\section{Saeid Doaei}

Guilan University of Medical Sciences

\section{Mohammad Reza Haghshenas}

Shiraz University of Medical Sciences

Zohreh Mazloom ( $\sim$ Zohreh.Mazloom@gmail.com )

Shiraz University of Medical Sciences

\section{Research Article}

Keywords: Breast Cancer, Trypsin Inhibitor, Angiogenesis, Melon seed extract

Posted Date: January 11th, 2022

DOI: https://doi.org/10.21203/rs.3.rs-1239363/v1

License: (c) (i) This work is licensed under a Creative Commons Attribution 4.0 International License. Read Full License 


\section{Abstract}

\section{Background}

Melon seeds as an excellent supply of protease inhibitors may have a protective role against tumor progression and angiogenesis. However, its effects on angiogenesis and the mechanism of its motion on cancer progression remain elusive. This study aimed to investigate the effect of bioactive compounds of melon seed on the expression of angiogenesis genes in breast cancer cell lines.

\section{Methods}

Trypsin inhibitor ( $\mathrm{TI})$ was purified from the seed powder of Cucumis Melo. Half-maximal inhibitory concentration (IC50) was determined for TI, extract of melon seed powder (EXT), and tamoxifen (TAM) by MTT test. Also, breast tumor was induced by subcutaneous injection of MC4-L2 cell line in blab-c inbreed mice breast tissue. After tumor growth, mice were treated with TI, EXT, and TAM to examine their effects on the tumor characteristics and the expression of the angiogenesis-related genes including MMP-2, MMP-9, and VEGF using the RT-PCR method.

Results

TI, EXT, TAM, and adjuvant treatment of TI+TAM resulted a reduction in expression of MMP-2, MMP-9, and VEGF. All treatments improved the breast tumor characteristics and the necrosis. The Real Time-PCR method verified the positive effects of the treatments on the breast cancer cell line and tumors.

Conclusion

The results indicated that treatments with trypsin Inhibitor Purified from Cucumis Melo Seeds and also combination therapy of trypsin inhibitor and tamoxifen can be considered as an alternative therapy in breast cancer patients. Further studies are warranted.

\section{Introduction}

Breast cancer is known as the most commonly diagnosed and the second leading cause of cancerrelated mortality in women $(1,2)$. Similar to most solid tumors, breast cancer requires new blood vessel growth, and these new vessels not only help to meet the growing metabolic demands of the tumor by supplying additional nutrients but also provide potential routes for tumor dissemination and metastasis (3). In breast cancer, tumor-induced angiogenesis is first evident at the pre-invasive stage of high-grade ductal carcinoma (4) . It is now evident that tumors have a very limited capacity to grow without vascular support. Therefore, the formation of blood vasculature is an obligatory step to sustain the influx of essential nutrients to the cancer cells $(5,6)$.

Some proteases such as matrix metalloproteinase (MMPs) are considered to play important roles in immune responses, inflammatory reactions, and tissue remodeling $(7,8)$. Recent studies confirmed that 
the expression of MMPs in tumor cells is closely correlated to their metastatic activity (9). The MMP axis has several areas of overlap with the cytokine network and inflammatory cytokines or growth factors can regulate the expression of MMPs. Cytokines and growth factors play an important role in promoting the activation of MMPs from the inactive zymogens to the active enzymes. In a recent study, several endothelial growth factors including vascular endothelial growth factor (VEGF) were demonstrated to promote neovascularization (10). In fact, VEGF is a specific mitogen and survival factor for endothelial cells and a key promoter of physiological and pathological angiogenesis (11-13).

HER2 is a protein that helps breast cancer cells grow quickly. Breast cancer cells with higher than normal levels of HER2 are called HER2-positive. These cancers tend to grow and spread faster than breast cancers that are HER2-negative, but are much more likely to respond to treatment with drugs that target the HER2 protein. The advancement of focused on HER2 treatments, has altogether progressed the result for patient with HER2 positive breast cancer(14). Tamoxifen (TAM) is considered a gold standard in the treatment of estrogen receptor (ER)-positive breast cancer (15). Estrogen receptors are one of the most important targets for controls of carcinogenesis and inhibition of tumor cell growth. This drug is also effective as adjuvant therapy and considerably improves follow-up outcomes of surgery by reducing the risk of disease recurrence and death. Tamoxifen antitumor effect is first of all due to the ability to selectively block the ERs found in most breast cancer patients (15). However, some side effects of TAM appear in breast cancer patients with long-term therapy (16).

Some plant-derived compounds such as flavonoids, phytoestrogens, and protease inhibitors were reported to be able to prevent one-third of cancers $(17,18)$ and inhibit tumor cell proliferation and new vessel formation in tumors without major side effects and significant toxicity to normal tissues $(17,19)$. These natural compounds can provide protection against inflammatory diseases through the regulation of inflammatory pathways (19). Some plants such as melon extract and its trypsin inhibitor protein has many biological functions including anti oxidative, anti-inflammatory, and anticancer effects (17). Melon seeds can be used as a source of nutrients, natural antioxidants, and bioactive compounds (20). Recent studies showed that different component of melons have anticancer role by affecting on a variety of different mechanisms including cell proliferation, autophagy, level of insulin-like growth factor 1 receptor and its downstream signaling pathway. But the main mechanism and its antiangiogenic effects in breast cancer is unknown (21-24).

The present study aimed to investigate the effect of bioactive compounds of melon seed including TI protein and its EXT on the expression of angiogenesis genes including MMP-2\&9 and VEGF in-vivo and in-vitro on MC4-L2 breast cancer cell line. We also assessed the changes in tumor tissue characteristics in the mice model such as inflammation, necrosis, angiogenesis, cell proliferation, and tumor size.

\section{Materials And Methods}

\section{Seed preparation of target plant}


First, the seeds of the melon plant were prepared through washing it to remove any kind of contamination. The seeds were then dried indirectly using sunlight and the kernels were separated and crushed using a grinder. The resulting powder was used as a starting material to purify the target peptides by chromatography.

\section{Preparation of affinity column with trypsin ligand and chromatography}

After preparation of the specified seed powder, the chromatography method was done as previously described elsewhere (25). Only, in the last step, the supernatant was loaded onto the column, and therefore the column was washed with deionized water until the absorbance of fractions at $280 \mathrm{~nm}$ came to zero. Three column volumes of deionized water with $\mathrm{PH}=2.5$ accustomed to wash sure proteins from the column (deionized water was adjusted to $\mathrm{PH}=1.5$ with $0.1 \mathrm{~N} \mathrm{HCl}$ ).

\section{Polyacrylamide gel electrophoresis}

Polyacrylamide gel electrophoresis was performed in the presence of sodium dodecyl sulfate SDS-PAGE based on the Schagger and Von Jagow method (26) as previously explained (25).

\section{Measurement of protein concentration}

The final and quantitative protein concentrations were determined by the Bradford method as the standard procedure (27).

\section{Assay of Tl activity}

The activity of the Trypsin inhibitor from Cucumis melo (Muskmelon) was determined by the residual trypsin activity following the method of Hajela (28) with slight modifications using N-a-benzoyl-DLarginine-pnitroanilide (BApNA) as the substrate and bovine trypsin as the standard enzyme. The reaction mixture containing $50 \mu \mathrm{l} \mathrm{Tl}(5 \mathrm{mg} / \mathrm{ml}), 50 \mu \mathrm{l}$ trypsin $(1 \mathrm{mg}$ in $5 \mathrm{~mL}$ of $0.05 \mathrm{M}$ Tris- $\mathrm{HCl}, \mathrm{pH}$ 8.0, containing $0.03 \mathrm{M} \mathrm{CaCl} 2)$ and $100 \mu \mathrm{l} 0.05 \mathrm{M} \mathrm{Tris}-\mathrm{HCl}(\mathrm{pH} 8.0)$ containing $0.03 \mathrm{M} \mathrm{CaCl} 2$ was incubated at $37^{\circ} \mathrm{C}$ for $10 \mathrm{~min}$ in a shaking water bath. The residual activity was measured by adding $1 \mathrm{~mL}$ of $0.8 \mathrm{mM}$ BApNA (7 $\mathrm{mg}$ dissolved in a minimum volume of DMSO and adjusting its final volume to $20 \mathrm{~mL}$ with $0.05 \mathrm{M}$ Tris$\mathrm{HCl}, \mathrm{pH}=8.0$, containing $0.03 \mathrm{M} \mathrm{CaCl} 2$ ) to the reaction mixture followed by incubation at $37^{\circ} \mathrm{C}$ for $10 \mathrm{~min}$ in a shaking water bath. The reaction was stopped by adding $20 \mu \mathrm{l}$ of $30 \%(\mathrm{v} / \mathrm{v})$ glacial acetic acid. A blank and a trypsin control were run simultaneously. In blank, acetic acid was added prior to the addition of BApNA and in trypsin control, distilled water was added in place of the TI. The absorbance was recorded at $410 \mathrm{~nm}$ against the blank using a double beam UV-visible spectrophotometer (Model 2202, Systronics, India). An appropriate volume of the kidney bean extract, which was enough to give $40-60 \%$ inhibition of trypsin, was taken for the assay. One trypsin unit (TU) was defined as an increase of 0.01 absorbance units at $410 \mathrm{~nm}$ per $1.2 \mathrm{~mL}$ of the reaction mixture. TI activity was expressed as the number of trypsin units inhibited (TUI).

\section{In-vitro phase}




\section{Cell line and culture conditions}

MC4-L2 mouse breast cancer cell lines (National Center for Genetic and Biological Resources of Iran, Tehran) were maintained and grown in 25 and $75 \mathrm{~cm} 2$ flasks (SPL, Pocheon, Korea) in DMEM: Ham's F12 + $2 \mathrm{mM} \mathrm{L-Glutamine}+15 \mathrm{mM}$ HEPES buffer, penicillin $(100 \mu \mathrm{g} / \mathrm{ml})$, streptomycin $(100 \mu \mathrm{g} / \mathrm{ml})$, and $10 \%$ (vol/vol) fetal bovine serum (FBS, Gibco BRL, Life Technologies, Grand Island, NY) in a $37^{\circ} \mathrm{C}$ incubator and $5 \% \mathrm{CO} 2$. Cells were monitored by a phase-contrast microscope until they reached appropriate confluence. Once the cells reached $90 \%$ confluency, the MC4-L2 cells was harvested with $0.25 \%$ trypsin- $0.02 \%$ ethylenediaminetetraacetic acid (EDTA). Cell viability and numbers were determined by a hemocytometer and trypan blue exclusion. Cell viability was calculated to be greater than $98 \%$.

\section{Cell viability assay in vitro}

Toxicity and cell proliferation were assessed using the MTT Sigma test. First, to determine and set up the exact number of cells required to perform the desired test in a 96-'s pellet in 8 rows of 12 wells, different values of $5 * 10^{3}, 10 * 10^{3}, 15 * 10^{3}, 20 * 10^{3}, 25 * 10^{3}, 30 * 10^{3}, 50 * 10^{3}$ and $100 * 10^{3}$ of MC4-L2 sol were poured into $10 \%$ FBS-enriched DMEM-F12 medium to evaluate cell growth. After 24 hours, the cell growth rate was examined using a microscope and the number of $10^{4}$ cells per well of the pellet had the best response, which was selected as the number of cells approved for MTT testing. To perform the MTT test, $10^{4}$ cells of MC4-L2 cell line were poured into each of 96 culture pellets and then $10 \%$ FBS enriched with $100 \mathrm{ml}$ of DMEM-F12 culture medium per $100 \mathrm{ml}$ was added. After 24 hours of incubation at $37^{\circ} \mathrm{C}$ with $5 \%$ CO2, different concentrations of $\operatorname{TI}(5,10,25,50,100,200,300,400,800,1200 \mu \mathrm{g} / \mathrm{ml})$, EXT (5, $10,25,50,100,200,400,800,1200 \mu \mathrm{g} / \mathrm{ml})$ and, TAM $(0.01,0.1,1,5,10,15,20 \mu \mathrm{moll})$ were added to each well and then $100 \mathrm{ml}$ of the desired culture medium was added. The cells were incubated again for 48 hours and these steps were repeated 3 times for all concentrations. After 48 hours of incubation at $37^{\circ} \mathrm{C}$ with $5 \% \mathrm{CO} 2$, equivalent to 10 microliters of 3- (4,5-dimethylthiazole-2) -2,5-diphenyltetrazolium bromide MTT solution (Sigma) $(0.5 \mathrm{mg} / \mathrm{ml}$ MTT powder in PBS), was added to each of the culture medium houses and incubated again for 4 hours at $37^{\circ} \mathrm{C}$ with 5\% CO2 and then centrifuged at $3000 \mathrm{rpm}$ for 10 minutes. To dissolve the Formazan crystal, the supernatant containing MMT was completely removed and $200 \mathrm{ml}$ of dimethyl sulfoxide (DMSO) was added to each well and kept at room temperature for 30 minutes to dissolve completely. The ELISA reader was read at $570 \mathrm{~nm}$ and $630 \mathrm{~nm}$.

\section{Examination of anti-angiogenesis effects of TI, EXT, and TAM}

According to MTT results and after preparation of the MC4-L2 cell line, $10^{4}$ cells were poured into each well of a 96-well plate and placed in an incubator for 24 hours. Then we emptied the medium on the wells and $500 \mu \mathrm{l}$ of fresh medium with $10 \%$ FBS was added to the wells. The Control group received no treatment. Treatments groups were designed as BPS solution, $5 \mu \mathrm{moll}$ of TAM, $400 \mu \mathrm{g} / \mathrm{ml}$ of EXT, TI at concentrations of 200 and $300 \mu \mathrm{g} / \mathrm{ml}$, and $300 \mu \mathrm{g} / \mathrm{ml}$ of TI $+5 \mu \mathrm{moll}$ of TAM. Then the plates were incubated at a $\mathrm{CO} 2$ incubator for $72 \mathrm{~h}$. Treatments were carried out in five for each dose. Finally, the antiangiogenesis effects were examined using fluorescent staining and the RT-PCR method. 


\section{Fluorescent staining method and viability test}

PBS 1X solution, FDA (Fluorescein Diacetate) and, PI (Propidium lodide) were used in a proportion of 1 $\mathrm{ml}, 10 \mu \mathrm{l}$, and $100 \mu \mathrm{l}$, respectively. Images were recorded using a microscope camera (Fig 1).

\section{Animal Phase}

\section{Experimental animals and tumor model}

The Ethics Committee at Shiraz University of Medical Sciences approved the experiments (IR.SUMS.REC.1398.950). Five to six weeks-old normal female BALB/c inbreed female mice were purchased from Pasteur Institute (Tehran, Iran). The mice were housed in an animal facility at a temperature of $22-24^{\circ} \mathrm{C}$ and $65 \%$ humidity. Trypsinized MC4-L2 cells were then harvested and washed to induce tumor formation in the mice. Their concentration was adjusted to $3.5 \times 10^{6}$ cells $/ 100 \mu$ with phosphate-buffered saline (PBS) at less than $98 \%$ viability. Prepared cells were injected subcutaneously into the right upper thigh of each mouse. Approximately 7-10 days after injection of the cancer cells, the tumors were palpated in the injected areas. The BALB/c inbreed mice were randomly devided into six groups of five mice per group: controlled breast cancer mice without any treatment (normal control group), breast cancer mice treated with either $300 \mu \mathrm{gr} / \mathrm{ml}$ or $600 \mu \mathrm{gr} / \mathrm{ml}$ of Tl, breast cancer mice treated with $800 \mu \mathrm{gr} / \mathrm{ml}$ of EXT, breast cancer mice group received $10 \mu \mathrm{mol}$ TAM and the last group was breast cancer mice that received combination therapy of $600 \mu \mathrm{gr} / \mathrm{ml}$ of TI $+10 \mu \mathrm{mol}$ TAM. The treatment period duration was 14 days. Finally, the mice were first anesthetized and then killed, and their tumor tissue was extracted and stored in $10 \%$ formalin.

\section{Histological assessments}

Tissue passage steps, preparation of paraffin blocks, and preparation of 5-micron sections were performed. H\&E staining method was performed for histological assessments using undiluted Mayer's hematoxylin (Merck, Darmstadt, Germany) and 0.5\% eosin (Merck). Evaluations were performed by light microscope (Olympus cx31) for the intensity and scoring of inflammation $(-,-/+$, and $+/+)$, necrosis (\%), and peripheral vessels as angiogenesis $(+,++,+++)$ (Fig 2 ).

\section{Molecular phase}

\section{RNA extraction and cDNA synthesis}

Total RNA extraction was extracted from MC4-L2 cell line-treated and tumor tissues of mice using TRIZOL reagent (Gene All, South Korea), according to the manufacturer's instructions. RNA concentrations were determined using the NanoDrop spectrophotometer (Thermo Scientific, Germany). The quality of extracted RNA was assessed by $1 \%$ agarose gel electrophoresis. After RNA extraction, the complementary DNA (cDNAs) were synthesized using a cDNA synthesis kit (EURx, Poland), according to the manufacturer's instructions. 


\section{Quantitative real-time polymerase chain reaction}

Real-time polymerase chain reaction (PCR) was used to determine the expression levels of MMP-2, MMP9, and VEGF genes in the MC4-L2 cell line and tumor tissue of mice.

Designing of primers used for RT-PCR were done by Allele ID 6 software and are listed in Table 1. Subsequently, the primer specificity was confirmed by Primer-BLAST (https://www.ncbi.nlm.nih.gov/tools/primer-blast) and In-Silico PCR (https://genome.ucsc.edu/cgibin/hgPcr. The human glyceraldehyde-3-phosphate dehydrogenase (GAPDH) gene was considered as the housekeeping gene (internal control).

The real-time PCR reactions were performed in duplicates using the SYBR Green PCR master kit (EURx, Poland) in a real-time PCR instrument (Applied Biosystems, USA). The expression of interested genes (MMP-2, MMP-9, and VEGF) at transcript level were normalized to the GAPDH gene expression, and the standard deviations were calculated. Relative real-time PCR was performed in duplicates, and each experiment was repeated two times. The program for thermocycling was as follows: 1 cycle at $95^{\circ} \mathrm{C}$ for 2 min, followed by 40 cycles at $95^{\circ} \mathrm{C}$ for 30 seconds, and then 1 cycle at $65^{\circ} \mathrm{C}$ for 20 seconds. Finally, the relative quantification of the gene expression was achieved using the comparative Ct method (29).

Table 1: Nucleotide sequences of the primers used for the gene expression analysis by real-time PCR.

\begin{tabular}{lll} 
Aneling temperature & Oligo Sequence 5'-> 3' & Gene \\
\hline 59 & Forward primer TGATGGCATCGCTCAGATCC & MMP-2 primers \\
& Reverse primer TGTCACGTGGTGTCACTGTC & \\
\hline 59 & Forward Primer CGCTCATGTACCCGCTGTAT & MMP-9 primers \\
& Revers Primer GCCTTGGGTCAGGCTTAGAG & \\
\end{tabular}

58

Forward Primer CTGGAAGAATCGGGAGCCTG VEGFa primers

Revers Primer ACCACCGTGTCTTCTCTTGC

59

Forward Primer ACTGAGCAAGAGAGGCCCTA GAPDH

Revers Primer TATGgGgGtCTGGgATGGAA

\section{Statistical analyses}

Normal distribution of data on histopathological factors and tumor characteristics was assessed using the Kruskal-Wallis test. The statistical differences in the expression levels of genes and the fold changes 
in treated and control groups were compared using the Livak method $\left(2^{-\triangle \Delta C T}\right)$. One-way ANOVA was used for other parameters with LSD as the post-hoc test. Statistical analyses were performed using SPSS software (version 22.0; IBM Corporation, Armonk, NY, USA). The results were considered to be significant when the P-values were $<0.05$.

\section{Results}

\section{Protein purification and electrophoresis}

Electrophoresis analysis of purified protein Hejela method (28) identified a single band with a molecular mass of $3.4 \mathrm{kDa}$ (Fig 3). The results are presented as Supplementary file.

\section{Anti-proliferative effect of TI, EXT, and TAM}

The MTT results speculated that TI and EXT in doses of $5-1600 \mu \mathrm{gr} / \mathrm{ml}$ and TAM in doses of $0.01-20$ $\mu$ moll induced a significant reduction in the proliferation of MC4-L2 breast cancer cells which was dosedependent with an IC50 value of about $300 \mu \mathrm{gr} / \mathrm{ml}, 400 \mu \mathrm{gr} / \mathrm{ml}$, and $5 \mu$ moll respectively (Fig 4).

\section{Effect of TI, EXT and TAM on MMP-2, MMP-9 and VEGF secretion in vitro and in vivo}

In-vitro results on the MC4-L2 cell line showed a significant decrease in MMP-2 transcript gene expression in the groups receiving TI300 (99.9\%, P-value $<P<0.05)$ and TAM+TI300 $(99.92 \%$, $P$-value $<P<0.01)$ compared to the control group and PBS. There was no significant difference between the other groups (Fig 5-A). In addition, the expression of MMP-2 at the breast tumor tissue indicated a significant decrease in all groups included TAM, EXT800, TI300, TI600, and TAM+TI600 (98\%, 97.12\%, 97.93\%, 99.94\%, $99.99 \%$ respectively, $\mathrm{P}$-value $<\mathrm{P}<0.001)$ groups compared to control group.. There was also a significant decrease in the expression of the MMP-2 transcript gene in the TAM + TI600 (99.76\%, P-value $<\mathrm{P}<0.05)$ group compared to the EXT800 group. There was no significant difference between the other groups (Fig $6-A)$.

On the other hand, a significant reduction was observed in the expression of the MMP-9 transcript gene of the MC4-L2 cell line in the TAM+TI300 (99.93\%, P-value< $\mathrm{P}<0.01)$ group compared to the control group. Also, a significant decrease was found in the expression level of the MMP-9 transcript gene in the TI300 (99.65\%, $\mathrm{P}$-value $<\mathrm{P}<0.05)$ and TAM+TI300 (99.93\%, $\mathrm{P}$-value $<\mathrm{P}<0.01)$ groups compared to the PBS group. There was no significant difference between the other groups (Fig 5-B). In addition, the expression of the MMP-9 transcript gene of breast tumor tissue was significantly decreased in all study groups included TAM, EXT800, TI300, TI600, and TAM+TI600 (99.36\%, 98.86\%, 99.40\%, 99.98\%, 100\% respectively, $\mathrm{P}$-value $<\mathrm{P}<0.001)$ groups compared to control group. There was also a significant decrease in the expression of the MMP-9 transcript gene in the TI600 (98.24\%, P-value $<P<0.05)$ and TAM+TI600 $(99.74 \%$, $P$-value $<P<0.01)$ groups compared to the EXT800 group. There was no significant difference between the other groups (Fig 6-B). 
Regarding the VEGF transcript gene, the results of the study indicated a significant decrease in the expression of the VEGF transcript gene in both TI300 (99.87\%, P-value $<0.05)$ and TAM+TI300 (99.97\%, Pvalue $<0.01)$ groups compared to the control group in MC4-L2 cell line. Also, the expression of the VEGF transcript gene in the groups receiving TAM+TI300 (99.96\%, P-value $<0.05)$ showed a significant reduction compared to the PBS group. There was no significant difference between the other groups (Fig 5-C). The results showed a significant decrease in the expression of the VEGF transcript gene at the tumor tissue level in all treated groups, TAM, EXT800, TI300, TI600, and TAM+TI600 (98.83\%, 99.3\%, 99.57\%, 99.52\%, $99.98 \%$ respectively, P-value<0.001) groups compared to control group . There was no significant difference between the other groups (Fig 6-C).

\section{Effect of TI, EXT, and TAM on angiogenesis, inflammation, and tissue necrosis}

A significant decrease in the mean score of angiogenesis was observed in the groups receiving T1600 and TAM+TI600 compared to the control group at the levels of $(P=0.018)$ and $(P=0.009)$, respectively. There was no significant difference between the other groups (Fig 7-A).

The results showed a significant increase in the percentage of tumor tissue necrosis in the groups receiving TAM, EXT800, TI300, TI600 and TAM+TI600 compared to the control group $(P<0.027, P=0.016$, $P=0.009, P=0.004$, and $P<0.001$, respectively). Also, a significant increase was observed in TAM+TI600 group compared to the TAM and EXT800 groups $(P=0.024$ and $(P=0.041$, respectively). There was no significant difference between the other groups (Fig 7-B).

The results showed a significant increase in the mean score of inflammation in all groups compared to the control group $(P<0.001)$. There was no significant difference between the other groups $($ Fig $7-C)$.

\section{Effect of TI, EXT, and TAM on body weight and breast tumor tissue characteristics}

The results indicated no significant difference in body weight between groups over time (Fig 8-A). There was a significant decrease in the mean tumor volume in all treated groups, TAM $(131.94 \pm 6.83, P<0.001)$, EXT800(244.97 $\pm 90.14, P<0.01), T 1300$ (205.08 $\pm 54.79, P<0.001)$, TI600 (81.05 $\pm 13.73, P<0.001)$, and TAM+TI600 (161.13 $\pm 36.47, P<0.001)$ compared to the control group $(558.35 \pm 26.68)$. No significant difference was observed between the other groups on other days (Fig 8-B).

The results showed a significant reduction in the mean tumor width in all treated groups included TAM (5.88 $\pm 0.25, P<0.05), T I 300$ (5.62 $\pm 0.49, P<0.01), T I 600$ (5.22 $\pm 0.48, P<0.01)$, and TAM+TI600 (4.82 \pm 0.32 , $\mathrm{P}<0.001$ ) (except the group receiving EXT800) compared to the control group $(9.20 \pm 0.36)$. There was no significant difference between other groups on different days (Fig 8-C).

A significant decrease in mean tumor length was observed in the groups receiving TI600 $(4.72 \pm 0.28$, $\mathrm{P}<0.01)$ and TAM $(5.20 \pm 0.46, \mathrm{P}<0.01)$ compared to the control group $(9.08 \pm 0.33)$ in second week of treatment. No significant difference was observed between other groups on different days (Fig 8-D). 
There was a significant decrease in the mean tumor depth in the second week in all treated groups included TAM (3.78 $\pm 0.26, P<0.05)$, EXT800 (3.16 $\pm 0.45, P<0.01)$, TI300 $(3.44 \pm 0.23, P<0.01), T I 600$ $(2.57 \pm 0.34, P<0.01)$, and TAM + TI600 $(3.84 \pm 0.76, P<0.05)$ compared to the control group $(5.76 \pm 0.21)$. No significant difference was observed between the other groups on other days (Fig 8-E).

The results also show a significant decrease in the mean tumor weight in the groups receiving $\mathrm{TI} 300$ (0.124 $\pm 0.015, P<0.01), T I 600(0.099 \pm 0.013, P<0.01)$, and TAM + TI600 $(0.099 \pm 0.005, P<0.01)$ compared to the control group $(0.240 \pm .0 .022)$. Also, a significant reduction was observed in the groups receiving TI300 (0.124 $\pm 0.015, P<0.05), T I 600(0.099 \pm 0.013, P<0.01)$, and TAM $+T I 600(0.099 \pm 0.005, P<0.01)$ compared to the TAM group $(0.208 \pm 0.036)$. The groups receiving TI600 $(0.099 \pm 0.013, P<0.05)$ and TAM+TI600 $(0.099 \pm 0.005, P<0.05)$ showed a significant decrease compared to the EXT800 group. There was no significant difference between the other groups (Fig 9).

\section{Discussion}

This study was the first to explore the anti-angiogenic potential of C. Melo' TI, EXT, and combination therapy of TI and TAM in both in-vitro and in-vivo situations in the MC4-L2 breast cancer cell line and tumor tissue in mice (Fig 10). The results of the present study indicated that TI, EXT, TAM, and adjuvant treatment of TI+TAM resulted in a reduction in expression of MMP-2, MMP-9, and VEGF. All treatments improved the breast tumor characteristics and the necrosis. In general, the positive effects of the treatments on the breast cancer cell line and mouse animal model was reported. Melon is one of the medicinal plants that have various antitumor and antioxidant compounds. It is also one of the drug supplements that can be effective in the treatment of cancer with various mechanisms. This plant has anti-inflammatory, anti-proliferative, anti-tumor, antioxidant effects and can regulate immune system. One of the most important components of this plant's seed is protease inhibitors that are classified into cysteine protease inhibitors, serine protease inhibitors, and Metallocarboxy protease inhibitors $(25,30$, 31).

Previous studies were reported that protease inhibitors consumption can decrease the risk of cancer development by inhibition of angiogenesis (32). Since the formation of new blood vessels being one of the critical stages of tumor growth, angiogenesis inhibition can be one of the most important approaches of cancer prevention (33). The results of this study identified that TI and EXT in doses of $5-1600 \mu \mathrm{gr} / \mathrm{ml}$ and TAM in doses of 0.01-20 $\mu$ moll can induce a dose-dependent reduction in the proliferation of MC4-L2 breast cancer cell line.

In this study, the effect of 200 and $300 \mu \mathrm{gr} / \mathrm{ml}$ of Tl, $400 \mu \mathrm{gr} / \mathrm{ml}$ of EXT and $5 \mu \mathrm{moll}$ of TAM in MC4-L2 breast cancer cell line and 300 and $600 \mu \mathrm{gr} / \mathrm{ml}$ of Tl, $800 \mu \mathrm{gr} / \mathrm{ml}$ of EXT and $10 \mu \mathrm{moll}$ of TAM in mouse animal model with breast cancer was assessed along with a combination therapy of TI+TAM. The results identified that these treatments had a beneficial effect on angiogenesis inhibition by reduction or inhibition of MMP-2, MMP-9, and VEGF transcript gene expression. These treatments also could improve the breast tumor characteristics and had a beneficial effect on the increase of tumor necrosis and 
reduction of peripheral vessels in comparison to the control group. These effects were also more pronounced in TI and TAM+TI treated groups.

Rasouli et al. reported similar results of TI from C. Melo on the expression of angiogenesis-related gen such as VEGF, MMP-2\&9 in breast cancer cells (25). In another study, a similar effect of trypsin inhibitor protein extracted from soybean on inhibition of angiogenesis was obtained (34).

According to the previous studies, plant-derived compounds specifically inhibited tumor cell proliferation and new vessel formation in tumors without significant toxicity to normal tissues and major side effects $(19,35)$. Also, several studies have already reported the cytotoxic, antioxidant/anti-inflammatory, and immunomodulatory effects of this fruit extract (36).

Melon seeds were reported to be a good source of natural active components and have antioxidant properties (37-39). As a fact, plant seeds contain two major families of protease inhibitors, the Kunitz and Bowman-Birk inhibitors that have been earlier studied as anticancer agents (40-42). Some protease inhibitors from other sources have also been studied on cancer developement. Since the most common cause of cancer death in humans is angiogenesis-mediated metastasis of the primary tumor, angiogenesis modulation can be a promising approach to treat cancer $(43,44)$.

Angiogenesis is a multistep process involving degradation of basement membrane and extracellular matrix components, proliferation, migration, and tubulogenesis of endothelial cells, and finally maturation of the neovasculature. In the present study, TI and melon seed extract inhibited expression of VEGF, MMP-2\&9 from MC4-L2 cells, and breast tumor tissue in mice. VEGF, as the most important antiangiogenic factor, plays a key role during the angiogenesis process which involves induction of endothelial cell proliferation, migration, and also MMP secretion (45). According to these results, $\mathrm{TI}$ and EXT's suppressive effect on the expression of VEGF, MMP-2\&9 which affects other important events during angiogenesis, might be considered as one of the mechanisms of its anti-angiogenic activity. However, more studies are required to exactly determine the anti-angiogenesis mechanisms of $\mathrm{TI}$ and EXT.

Our results also found that all treatments led to an increase in necrosis and inflammation in tumor tissue and a significant decrease in peripheral vessels that led to a reduction of angiogenesis in comparison to the control group. The results also demonstrated that the TAM+TI600 group appeared to be more beneficial than the other treatments and the control group. Similar results were reported in some studies about TI and TAM's beneficial effects on necrosis, inflammation, and angiogenesis $(25,34,46)$.

Previous studies indicated that inflammation increased vascular permeability, in which the leukocytes migrate into the injured tissues. The inflammatory mediators like TNF-a, interferon- $y$, interleukins as well as chemokines play an important role in inflammation $(8,13)$. However, dysregulation of the inflammatory response may result in many disorders including autoimmune diseases and cancer (47). 
Our results identified that there was a significant reduction in tumor characteristics such as weight, length, depth, and volume in all treated groups in comparison to the control group. No published study has been investigated these outcomes yet. These changes may be due to the inhibition of angiogenesis and increases in tumor necrosis.

\section{Conclusion}

TI, EXT, and TAM therapy could inhibit the expression of angiogenesis-related genes such as MMP-2, MMP-9, and VEGF, and increase tumor tissue necrosis. They also cause positive changes in tumor tissue parameters such as length, width, depth, and height of the tumor with a dose-dependent effect.

Combination therapy by $\mathrm{TI}$ and TAM had the greatest effect on reducing tumor size, inhibiting the expression of angiogenesis-related genes and tissue necrosis. Further in-vivo and in-vitro studies will be warranted to confirm these results and to discover the molecular mechanisms.

\section{Abbreviations}

TI: Trypsin Inhibitor protein; EXT: Extract of C.Melo seed powder; TAM: Tamoxifen; MMPs: Matrix metalloproteinases; VEGF: Vascular endothelial growth factor; ERs: Estrogen receptors ; SDS-PAGE: sodium dodecyl sulphate-polyacrylamide gel electrophoresis; BApNA: N-a-benzoyl-DL-argininepnitroanilide; MTT: 2,3-bis-(2-methoxy-4-nitro-5-sulfophenyl)-2H-tetrazolium-5-carboxanilide; DMSO: Dimethyl sulfoxide; FDA: fluorescein diacetate; PI propidium iodide; GAPDH: Glyceraldehyde 3-phosphate dehydrogenase; RT-PCR: Reverse transcription polymerase chain reaction; EDTA: ethylenediaminetetraacetic acid.

\section{Declarations}

\section{Acknowledgments}

The results presented herein were extracted from the thesis written by Ms. Shahla Rezaei.

\section{Authors' contributions}

ShR and ZM designed the study. ShR and FK were involved in the data collection and analysis. ShR prepared the drafting of the manuscript. ShR, MH and, SD prepared the final draft of the manuscript. ShR, $\mathrm{FK}, \mathrm{NA}, \mathrm{MRH}, \mathrm{RY}$ were involved in the design of the study, analysis of the data, and critically reviewing the manuscript. All authors read and approved the final manuscript.

\section{Funding}

Funding for this study was provided by Shiraz University of Medical Sciences.

\section{Ethics approval and consent to participate}


The Ethics Committee at Shiraz University of Medical Sciences approved the protocol of the experiment (IR.SUMS.REC.1398.950).

\section{Availability of data and materials}

All the data used and/or analyzed during the current study are available from the corresponding author on eligible request.

\section{Conflict of interest}

The authors had no conflict of interest to declare.

\section{Competing interests}

The authors declare that they have no competing interests.

\section{References}

1. DeSantis CE, Ma J, Gaudet MM, Newman LA, Miller KD, Goding Sauer A, et al. Breast cancer statistics, 2019. CA: a cancer journal for clinicians. 2019;69(6):438-51.

2. Zheng S, Yang L, Zou Y, Liang J-y, Liu P, Gao G, et al. Long non-coding RNA HUMT hypomethylation promotes lymphangiogenesis and metastasis via activating FOXK1 transcription in triple-negative breast cancer. Journal of hematology \& oncology. 2020;13(1):1-15.

3. Folkman J. Angiogenesis in cancer, vascular, rheumatoid and other disease. Nature medicine. 1995;1(1):27-30.

4. Reuben SC, Gopalan A, Petit DM, Bishayee A. Modulation of angiogenesis by dietary phytoconstituents in the prevention and intervention of breast cancer. Molecular nutrition \& food research. 2012;56(1):14-29.

5. Kerbel RS. Tumor angiogenesis. New England Journal of Medicine. 2008;358(19):2039-49.

6. Schaaf MB, Garg AD, Agostinis P. Defining the role of the tumor vasculature in antitumor immunity and immunotherapy. Cell death \& disease. 2018;9(2):1-14.

7. Sava G, Capozzi I, Bergamo A, Gagliardi R, Cocchietto M, Masiero L, et al. Down-regulation of tumour gelatinase/inhibitor balance and preservation of tumour endothelium by an anti-metastatic ruthenium complex. International journal of cancer. 1996;68(1):60-6.

8. Johnson MD, Kim HRC, Chesler L, Tsao-Wu G, Polverini PJ, Bouck N. Inhibition of angiogenesis by tissue inhibitor of metalloproteinase. Journal of cellular physiology. 1994;160(1):194-202.

9. Kim A, Kim M-J, Yang Y, Kim JW, Yeom YI, Lim J-S. Suppression of NF-KB activity by NDRG2 expression attenuates the invasive potential of highly malignant tumor cells. Carcinogenesis. 2009;30(6):927-36.

10. Toi M, Taniguchi T, Yamamoto $Y$, Kurisaki T, Suzuki H, Tominaga T. Clinical significance of the determination of angiogenic factors. European Journal of Cancer. 1996;32(14):2513-9. 
11. Ribatti D, De Falco G, Vacca A, Nico B, Errede M, Roccaro AM, et al. Coordinate immunoreactivity to vascular endothelial growth factor receptor-2 and its ligand suggests a paracrine regulation during the development of the vascular system in the chick embryo bursa of Fabricius. International journal of molecular medicine. 2001;7(4):365-8.

12. Ribatti $D$, Vacca A, Dammacco F. New non-angiogenesis dependent pathways for tumour growth. European Journal of Cancer. 2003;39(13):1835-41.

13. Quaranta M, Daniele A, Coviello M, Venneri M, Abbate I, Caringella M, et al. MMP-2, MMP-9, VEGF and CA 15.3 in breast cancer. Anticancer research. 2007;27(5B):3593-600.

14. Incorvati JA, Shah S, Mu Y, Lu J. Targeted therapy for HER2 positive breast cancer. Journal of Hematology \& Oncology. 2013;6(1):1-9.

15. Ali S, Rasool M, Chaoudhry H, Pushparaj PN, Jha P, Hafiz A, et al. Molecular mechanisms and mode of tamoxifen resistance in breast cancer. Bioinformation. 2016;1.135:(3)2

16. Nakamura T, Imai Y, Matsumoto T, Sato S, Takeuchi K, Igarashi K, et al. Estrogen prevents bone loss via estrogen receptor $\alpha$ and induction of Fas ligand in osteoclasts. Cell. 2007;130(5):811-23.

17. Rasouli H, Farzaei MH, Mansouri K, Mohammadzadeh S, Khodarahmi R. Plant cell cancer: may natural phenolic compounds prevent onset and development of plant cell malignancy? A literature review. Molecules. 2016;21(9):1104.

18. Khuda-Bukhsh AR, Saha SK, Das S, Saha SS. Molecular approaches toward targeted cancer therapy with some food plant products: On the role of antioxidants and immune microenvironment. Cancer: Elsevier; 2021. p. 191-202.

19. Sagar S, Yance D, Wong R. Natural health products that inhibit angiogenesis: a potential source for investigational new agents to treat cancer-Part 1. Current Oncology. 2006;13(1):14-26.

20. Al-Khalifa A. Physicochemical characteristics, fatty acid composition, and lipoxygenase activity of crude pumpkin and melon seed oils. Journal of Agricultural and Food Chemistry. 1996;44(4):964-6.

21. Brennan VC, Wang C-M, Yang W-H. Bitter melon (Momordica charantia) extract suppresses adrenocortical cancer cell proliferation through modulation of the apoptotic pathway, steroidogenesis, and insulin-like growth factor type 1 receptor/RAC-a serine/threonine-protein kinase signaling. Journal of medicinal food. 2012;15(4):325-34.

22. Kwatra D, Subramaniam D, Ramamoorthy P, Standing D, Moran E, Velayutham R, et al. Methanolic extracts of bitter melon inhibit colon cancer stem cells by affecting energy homeostasis and autophagy. Evidence-Based Complementary and Alternative Medicine. 2013;2013.

23. Pongnikorn S, Fongmoon D, Kasinrerk W, Limtrakul P-N. Effect of bitter melon (Momordica charantia Linn) on level and function of natural killer cells in cervical cancer patients with radiotherapy. Journal of the Medical Association of Thailand= Chotmaihet Thangphaet. 2003;86(1):61-8.

24. Rolim P, Fidelis G, Padilha C, Santos E, Rocha H, Macedo G. Phenolic profile and antioxidant activity from peels and seeds of melon (Cucumis melo L. var. reticulatus) and their antiproliferative effect in cancer cells. Brazilian Journal of Medical and Biological Research. 2018;51. 
25. Rasouli H, Parvaneh S, Mahnam A, Rastegari-Pouyani M, Hoseinkhani Z, Mansouri K. Anti-angiogenic potential of trypsin inhibitor purified from Cucumis melo seeds: Homology modeling and molecular docking perspective. International journal of biological macromolecules. 2017;96:118-28.

26. Schägger $H$, Von Jagow $G$. Tricine-sodium dodecyl sulfate-polyacrylamide gel electrophoresis for the separation of proteins in the range from 1 to $100 \mathrm{kDa}$. Analytical biochemistry. 1987;166(2):368-79.

27. Bradford MM. A rapid and sensitive method for the quantitation of microgram quantities of protein utilizing the principle of protein-dye binding. Analytical biochemistry. 1976;72(1-2):248-54.

28. Hajela N, Pande A, Sharma S, Rao D, Hajela K. Studies on a doubleheaded protease inhibitor from Phaseolus mungo. Journal of Plant Biochemistry and Biotechnology. 1999;8(1):57-60.

29. Livak KJ, Schmittgen TD. Analysis of relative gene expression data using real-time quantitative PCR and the 2- $\triangle \Delta C T$ method. methods. 2001;25(4):402-8.

30. Ryan CA. Proteolytic enzymes and their inhibitors in plants. Annual Review of Plant Physiology. 1973;24(1):173-96.

31. Lawrence PK, Koundal KR. Plant protease inhibitors in control of phytophagous insects. Electronic Journal of Biotechnology. 2002;5(1):5-6.

32. Mills PK, Beeson WL, Abbey DE, Fraser GE, Phillips RL. Dietary habits and past medical history as related to fatal pancreas cancer risk among Adventists. Cancer. 1988;61(12):2578-85.

33. Mansouri K, Khodarahmi R, Foroumadi A, Mostafaie A, Motlagh HM. Anti-angiogenic/proliferative behavior of a "4-aryl-4 H-chromene" on blood vessel's endothelial cells: A possible evidence on dual "anti-tumor" activity. Medicinal Chemistry Research. 2011;20(7):920-9.

34. Shakiba Y, Mansouri K, Mostafaie A. Anti-angiogenic effect of soybean kunitz trypsin inhibitor on human umbilical vein endothelial cells. Fitoterapia. 2007;78(7-8):587-9.

35. Mousa AS, Mousa SA. Anti-angiogenesis efficacy of the garlic ingredient alliin and antioxidants: role of nitric oxide and p53. Nutrition and cancer. 2005;53(1):104-10.

36. Fan XM, Wong BCY, Wang WP, Zhou XM, Cho CH, Yuen ST, et al. Inhibition of proteasome function induced apoptosis in gastric cancer. International journal of cancer. 2001;93(4):481-8.

37. Yanty N, Lai O, Osman A, Long K, Ghazali H. Physicochemical properties of Cucumis melo var. inodorus (honeydew melon) seed and seed oil. Journal of Food Lipids. 2008;15(1):42-55.

38. Mallek-Ayadi S, Bahloul N, Kechaou N. Chemical composition and bioactive compounds of Cucumis melo L. seeds: Potential source for new trends of plant oils. Process Safety and Environmental Protection. 2018;113:68-77.

39. Zeb A. Phenolic Profile and Antioxidant Activity of Melon (Cucumis Melo L.) Seeds from Pakistan. Foods. 2016;5(4):67.

40. Barać M, Stanojević S, Pešić M. Biologically active components of soybeans and soy protein products: A review. Acta periodica technologica. 2005(36):155-68.

41. Fang EF, Ng TB. A trypsin inhibitor from rambutan seeds with antitumor, anti-HIV-1 reverse transcriptase, and nitric oxide-inducing properties. Applied biochemistry and biotechnology. 
2015;175(8):3828-39.

42. Fang EF, Wong JH, Ng TB. Thermostable Kunitz trypsin inhibitor with cytokine inducing, antitumor and HIV-1 reverse transcriptase inhibitory activities from Korean large black soybeans. Journal of bioscience and bioengineering. 2010;109(3):211-7.

43. Doñate F. Anti-angiogenic therapy in cancer. Drugs Future. 2005;30:695-707.

44. Eskander RN, Tewari KS. Incorporation of anti-angiogenesis therapy in the management of advanced ovarian carcinoma-mechanistics, review of phase III randomized clinical trials, and regulatory implications. Gynecologic oncology. 2014;132(2):496-505.

45. Tao H, Chen Z-W, Yang J-J, Shi K-H. MicroRNA-29a suppresses cardiac fibroblasts proliferation via targeting VEGF-A/MAPK signal pathway. International journal of biological macromolecules. 2016;88:414-23.

46. Elster N, Collins DM, Toomey S, Crown J, Eustace AJ, Hennessy BT. HER2-family signalling mechanisms, clinical implications and targeting in breast cancer. Breast cancer research and treatment. 2015;149(1):5-15.

47. Stetler-Stevenson WG, Liotta LA, Brown PD. Role of type IV collagenases in human breast cancer. Genes, Oncogenes, and Hormones. 1991:21-41.

\section{Figures}
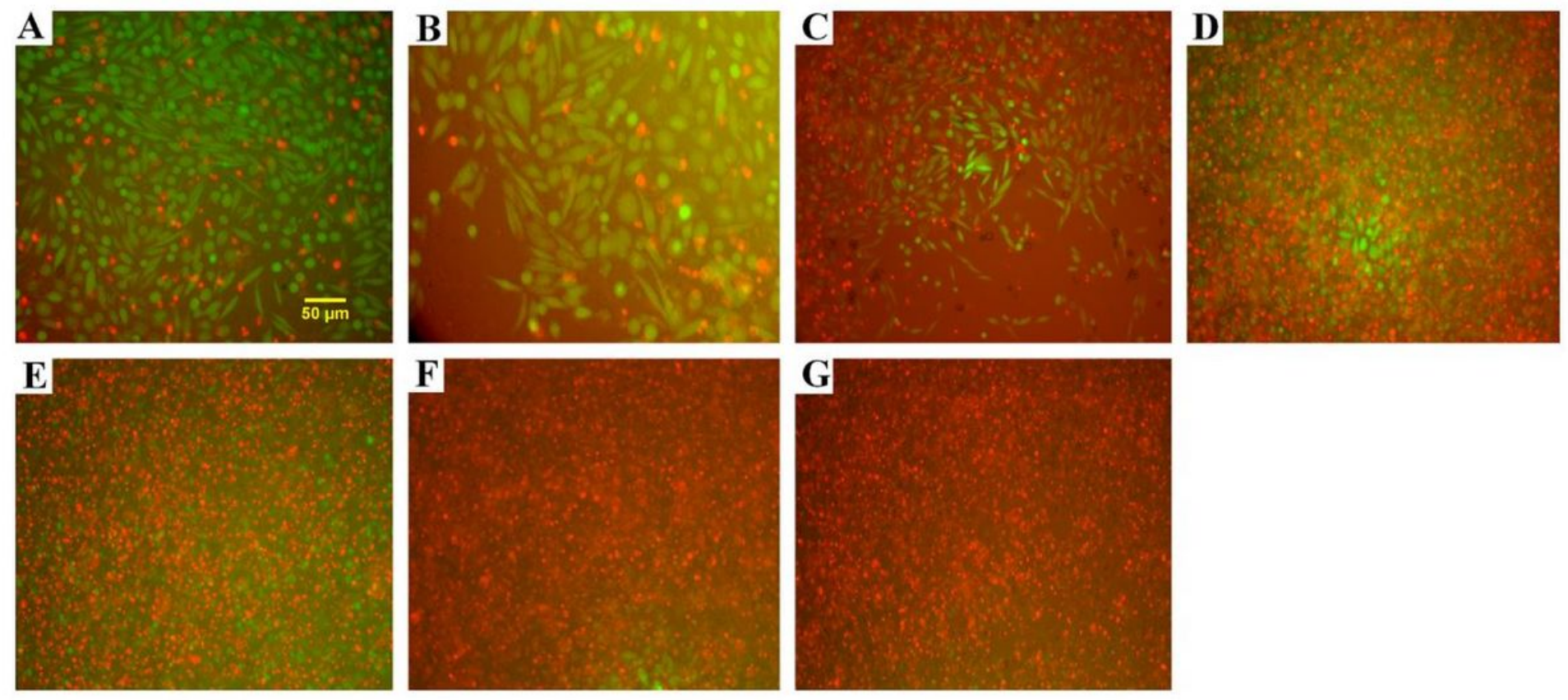

\section{Figure 1}

Evaluation of photomicrography by fluorescent staining method. A-G indicate control, tamoxifen $5 \mu \mathrm{mol}$, extract $400 \mu \mathrm{gr} / \mathrm{ml}$, trypsin inhibitor $200 \mu \mathrm{gr} / \mathrm{ml}$, trypsin inhibitor $300 \mu \mathrm{gr} / \mathrm{ml}$ and tamoxifen $5 \mu \mathrm{mol}+$ trypsin inhibitor $300 \mu \mathrm{gr} / \mathrm{ml}$ groups by inverted microscopy, respectively. 
Green and red areas represent living and dead cells, respectively.
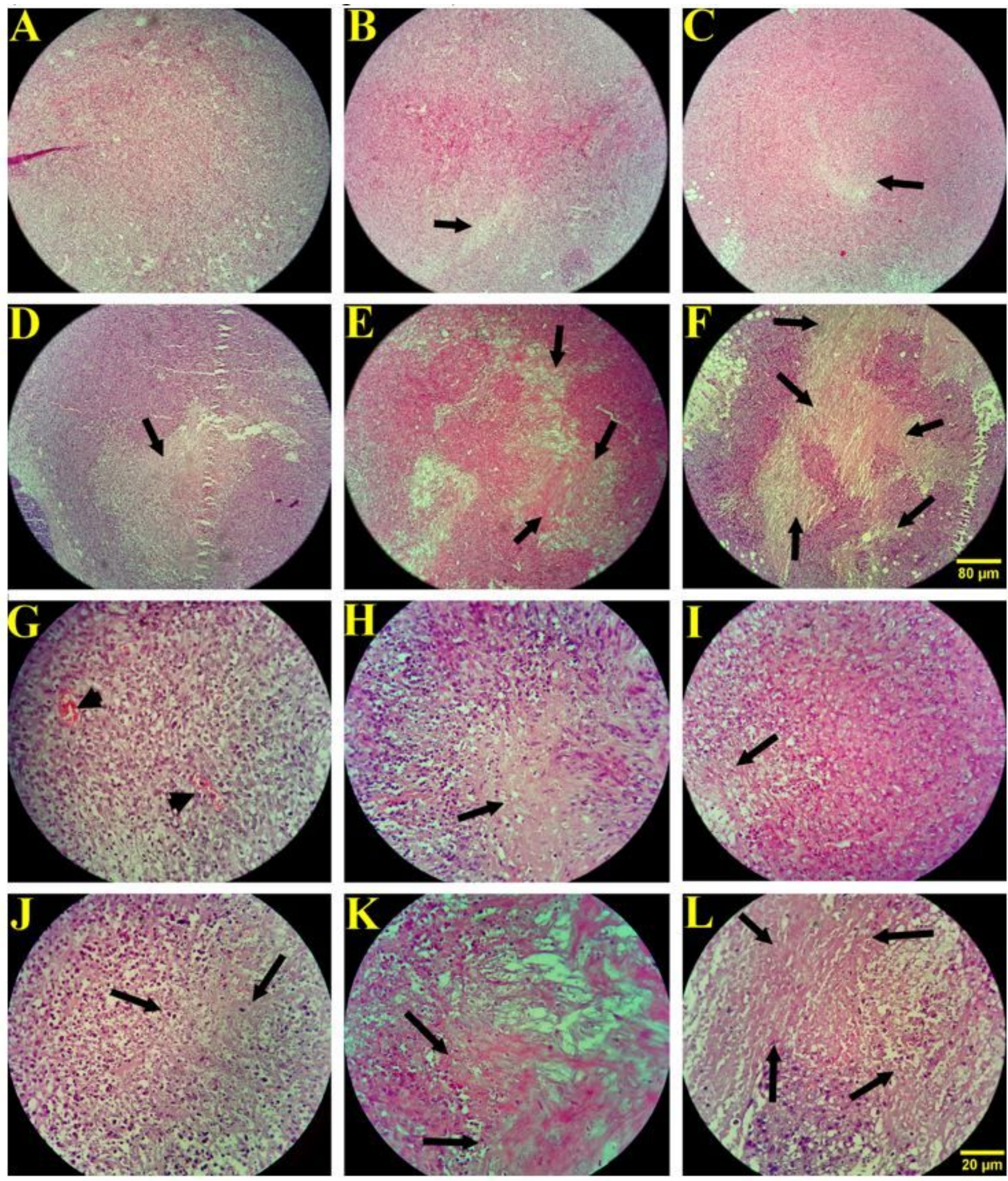

Figure 2 
Histopathology evaluation of breast tumor tissue in experimental groups by H\&E method (A-F* $100, \mathrm{G}-$ $L * 400$ indicate magnification). B\&H: breast cancer tamoxifen $10 \mu \mathrm{mol}$ group; C\&l: breast cancer extract $800 \mu \mathrm{gr} / \mathrm{ml}$ group; D\&J: breast cancer trypsin inhibitor $300 \mu \mathrm{gr} / \mathrm{ml}$ group; E\&K: breast cancer trypsin inhibitor $600 \mu \mathrm{gr} / \mathrm{ml}$ group; F\&L: breast cancer tamoxifen $10 \mu \mathrm{mol}+$ trypsine inhibitor $600 \mu \mathrm{gr} / \mathrm{ml}$. The white areas represent the shattered nuclei. The arrow sign indicates necrotic areas and the arrowhead indicates blood vessels.

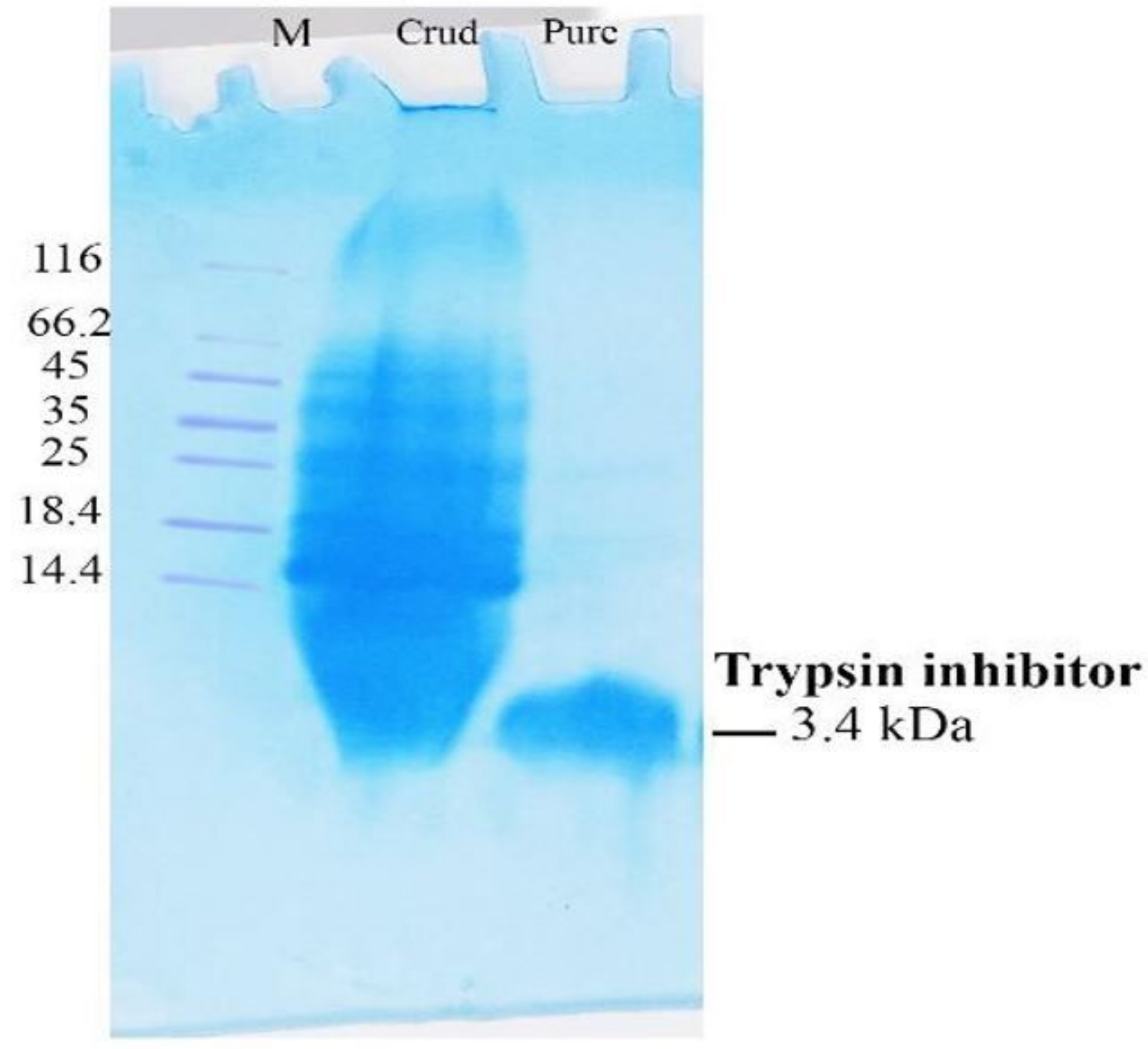

Figure 3

purified trypsin inhibitor from C. Melo 

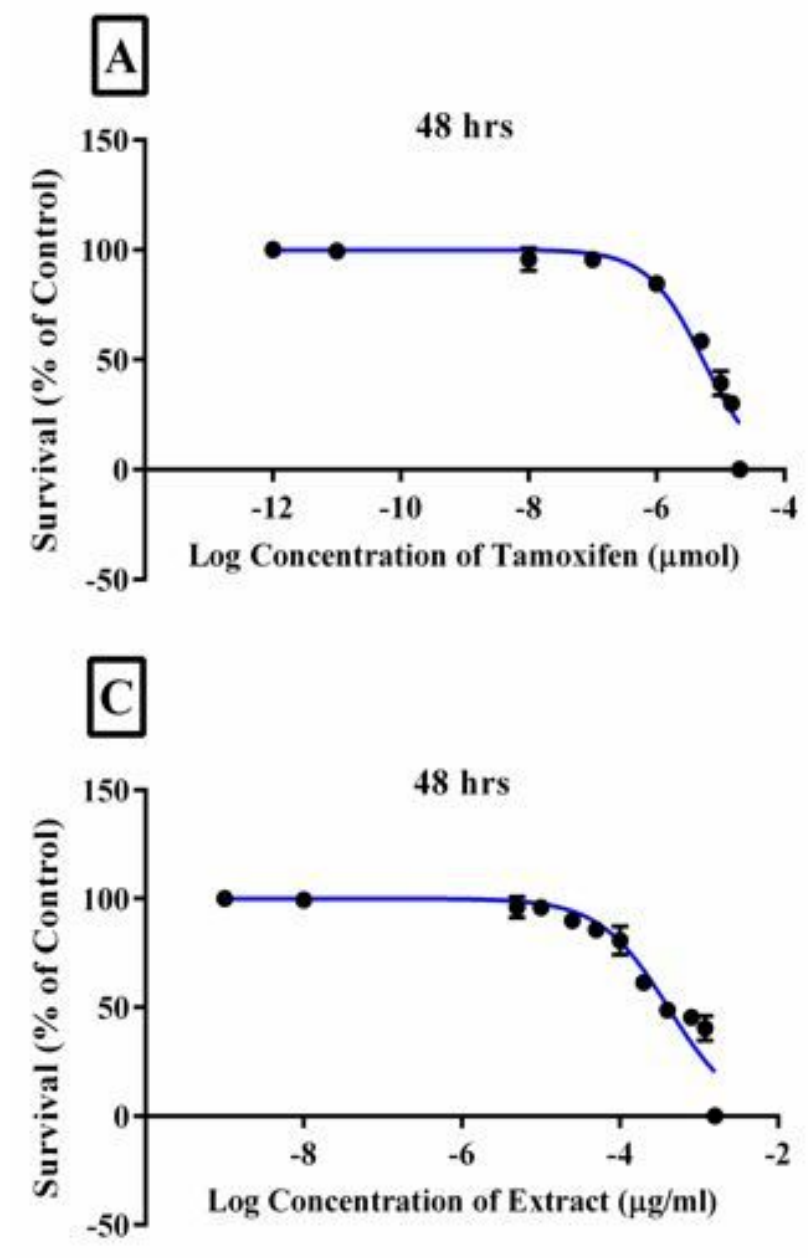

$\mathbf{E}$

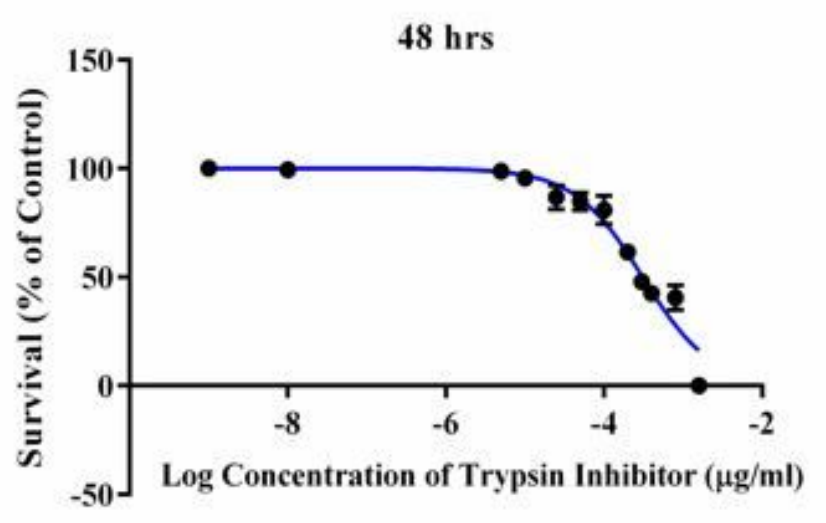

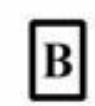

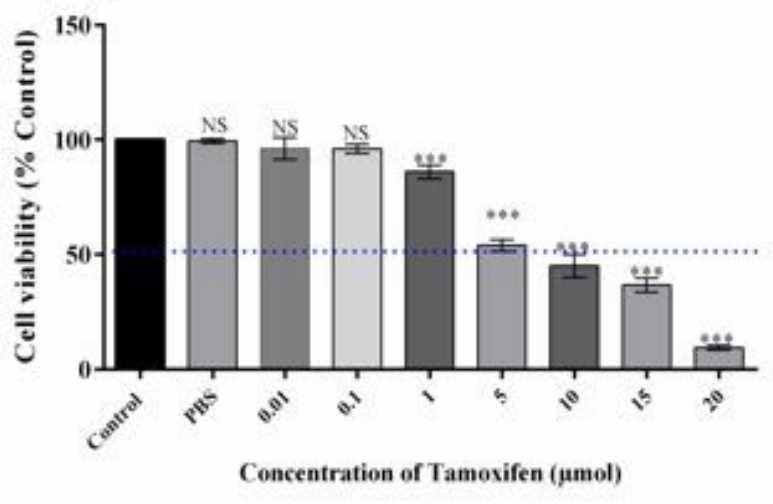

D

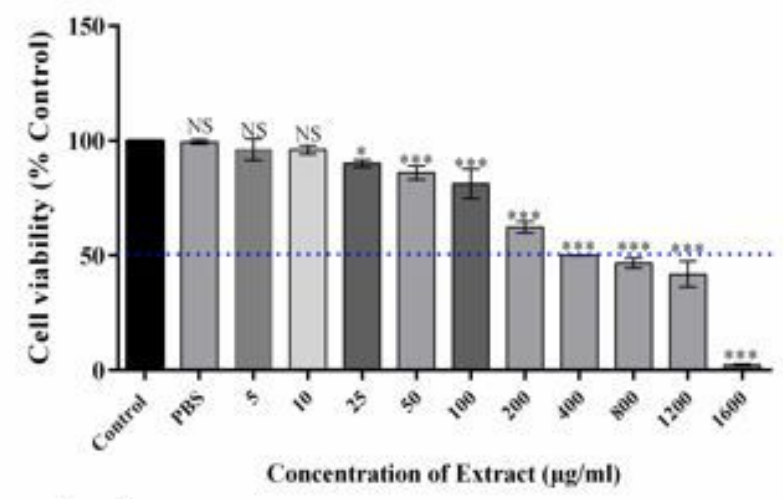

$\mathbf{F}$

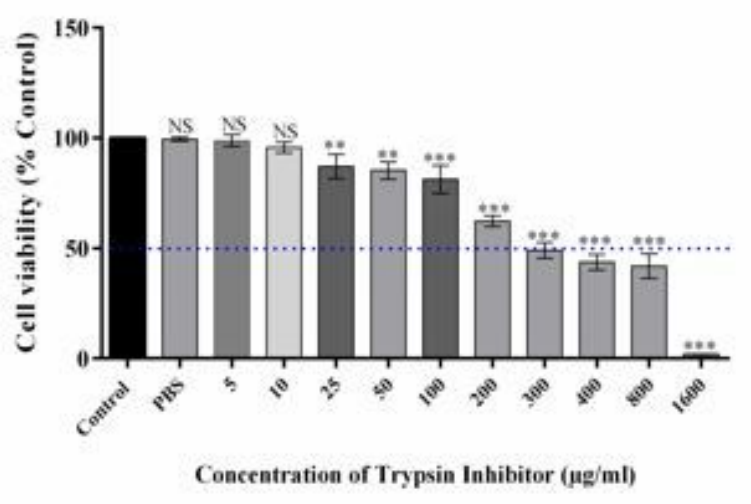

Figure 4

MTT assay of TAM, EXT, and TI on MC4-L2 cell line after 48h: (A, C, E) TAM, EXT and TI inhibited the growth of MC4-L2 cell line at 0.01-20 $\mu \mathrm{moll}, 5-1600 \mu \mathrm{g} / \mathrm{ml}$ respectively. Data are presented as mean \pm SD; B, D, F) TAM, EXT, and TI have no cytotoxic effect on MC4-L2 cell line at 0.01-20 $\mu \mathrm{moll}, 5-1600 \mu \mathrm{g} / \mathrm{ml}$, respectively. 
Q

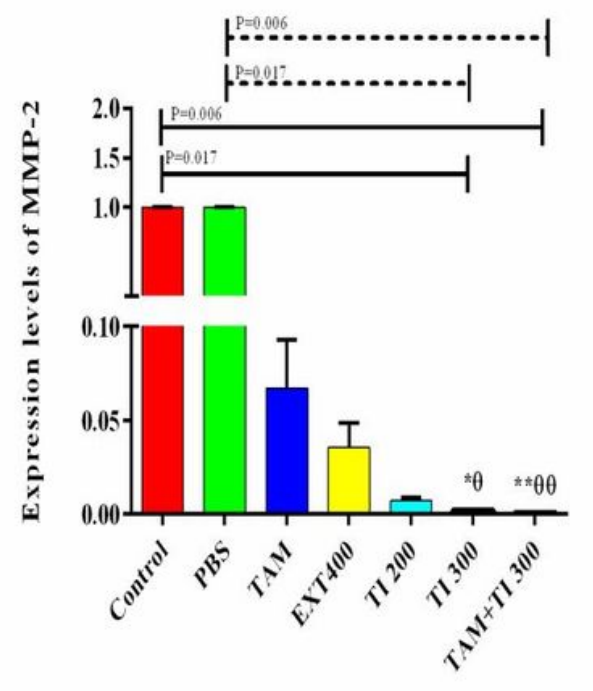

B

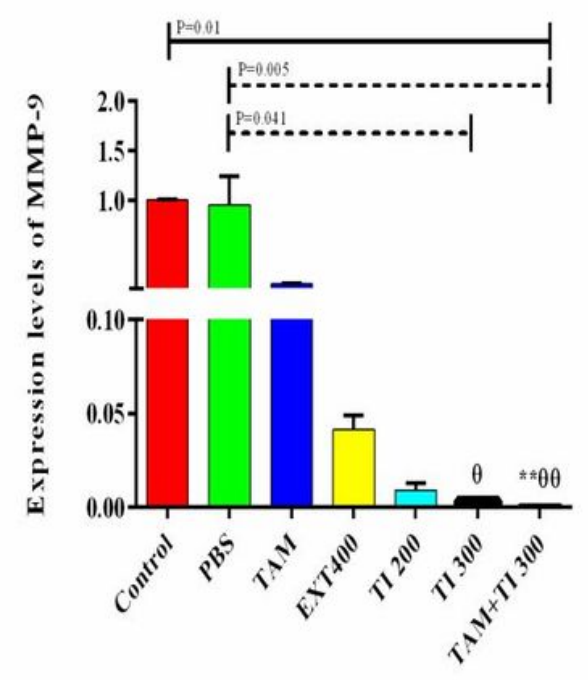



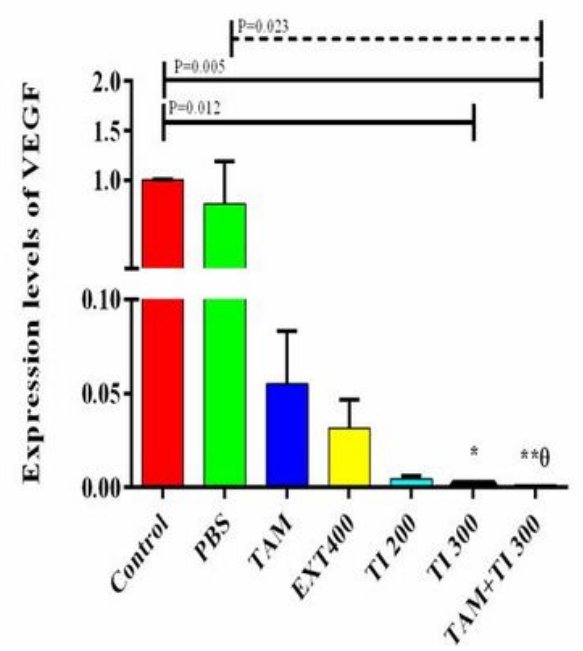

\section{Figure 5}

In-vitro evaluation of MMP-2, MMP-9, and VEGF secretion by RT-PCR method on MC4-L2 cell line(A-C). Control: Medium culture+MC4-L2 cell line as control group; BPS: Medium culture+MC4-L2 cell line + PBS solution; TAM: Medium culture+MC4-L2 cell line+tamoxifen 5 mol group; EXT400: Medium culture+MC4L2 cell line+extract $400 \mu \mathrm{gr} / \mathrm{ml}$ group; TI200: Medium culture+MC4-L2 cell line+trypsin inhibitor 200 $\mu \mathrm{gr} / \mathrm{ml}$ group; TI300: Medium culture+MC4-L2 cell line+trypsin inhibitor $300 \mu \mathrm{gr} / \mathrm{ml}$ group; TAM+TI600: Medium culture+MC4-L2 cell line+tamoxifen $5 \mu \mathrm{mol}+$ trypsin inhibitor $300 \mu \mathrm{gr} / \mathrm{ml}$. A) *, **: TI300 and

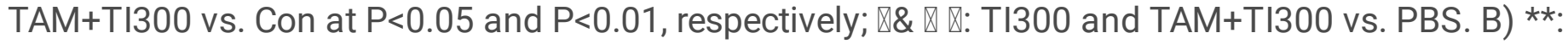
TAM+TI300 vs. Con at $P<0.01 ; \otimes \& \otimes \otimes: T 1300$ and TAM+TI300 vs. PBS. D) *, **: TI300 and TAM+TI300 vs.

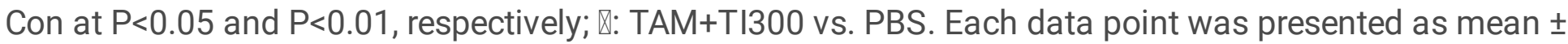
SD. 


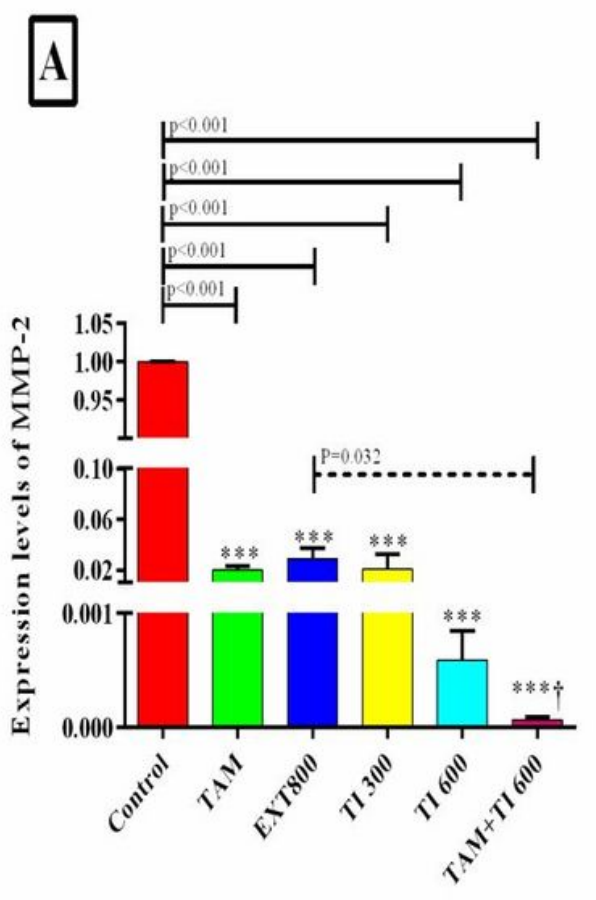

B
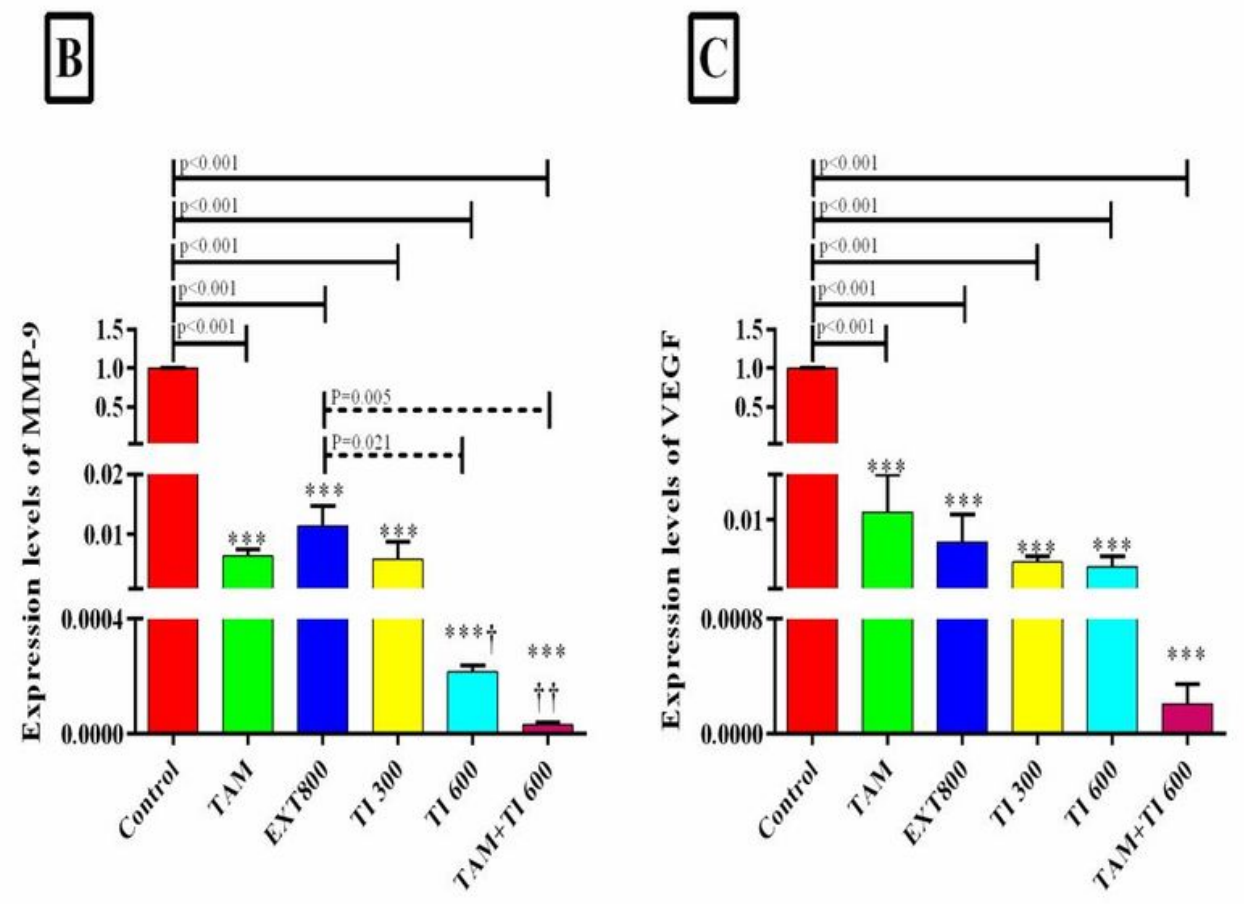

Figure 6

In-vivo evaluation of MMP-2, MMP-9, and VEGF secretion by RT-PCR method in breast cancer mice(A-C). Control: breast cancer control group; TAM: breast cancer tamoxifen $10 \mu \mathrm{mol}$ group; EXT800: breast cancer extract $800 \mu \mathrm{gr} / \mathrm{ml}$ group; TI300: breast cancer trypsin inhibitor $300 \mu \mathrm{gr} / \mathrm{ml}$ group; TI600: breast cancer trypsin inhibitor $600 \mu \mathrm{gr} / \mathrm{ml}$ group; TAM+T1600: breast cancer tamoxifen $10 \mu \mathrm{mol}+$ trypsin inhibitor $600 \mu \mathrm{gr} / \mathrm{ml}$. A) ${ }^{\star \star *}$ : All treated groups vs. Con at $\mathrm{P}<0.001 ;+$ : TAM+TI600 vs. EXT800. B) $\star * \star *$ : All treated groups vs. Con at $P<0.001 ; \dagger,+\dagger:$ TI600 and TAM+TI600 vs. EXT800. C) $\star \star *$ : All treated groups vs. Con at $P<0.001$. Each data point was presented as mean \pm SD. 
A

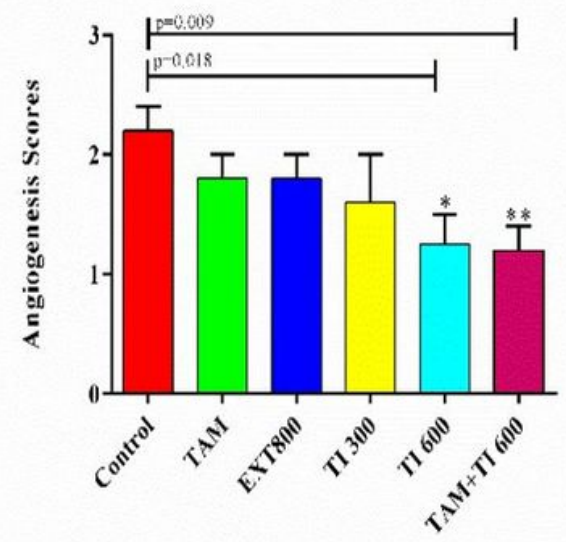

B

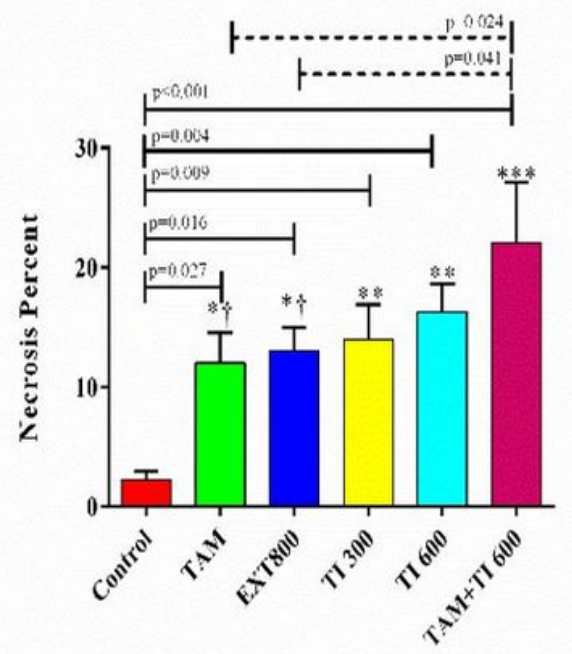

C

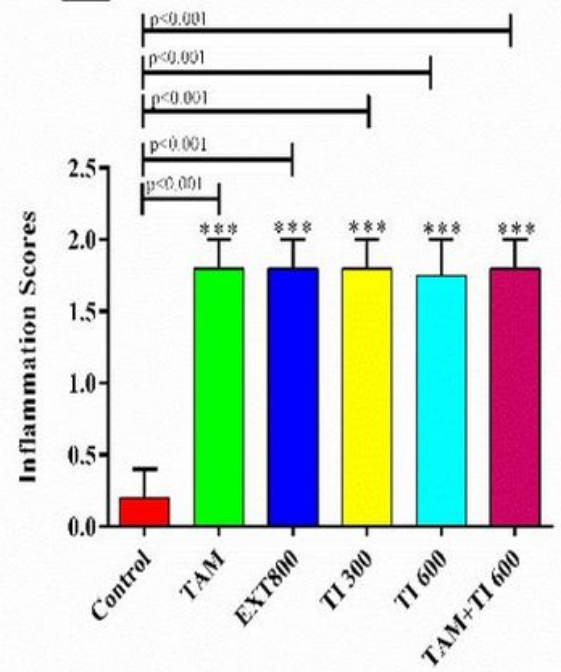

Figure 7

Evaluation of angiogenesis, necrosis, and inflammation of breast tumor tissue (A-C). Control: breast cancer control group; TAM: breast cancer tamoxifen $10 \mu \mathrm{mol}$ group; EXT800: breast cancer extract 800 $\mu \mathrm{gr} / \mathrm{ml}$ group; TI300: breast cancer trypsin inhibitor $300 \mu \mathrm{gr} / \mathrm{ml}$ group; TI600: breast cancer trypsin inhibitor $600 \mu \mathrm{gr} / \mathrm{ml}$ group; TAM+TI600: breast cancer tamoxifen $10 \mu \mathrm{mol}+$ trypsin inhibitor $600 \mu \mathrm{gr} / \mathrm{ml}$. A) angiogenesis: * ${ }^{* *}$ : TI600 and TAM+TI600 vs. Con at $\mathrm{P}<0.05$ and $\mathrm{P}<0.01$, respectively; $\left.\mathrm{B}\right)$ necrosis: *, $\star *$, ***: TAM, EXT800, TI300, TI600 and TAM+TI600 vs. Con at $\mathrm{P}<0.05, \mathrm{P}<0.01$ and $\mathrm{P}<0.001$, respectively; †: TAM+TI600 vs. TAM and EXT800. C) inflammation: $\star \star *$ : All treated groups vs. Con at $P<0.001$. Each data point was presented as mean \pm SD. 

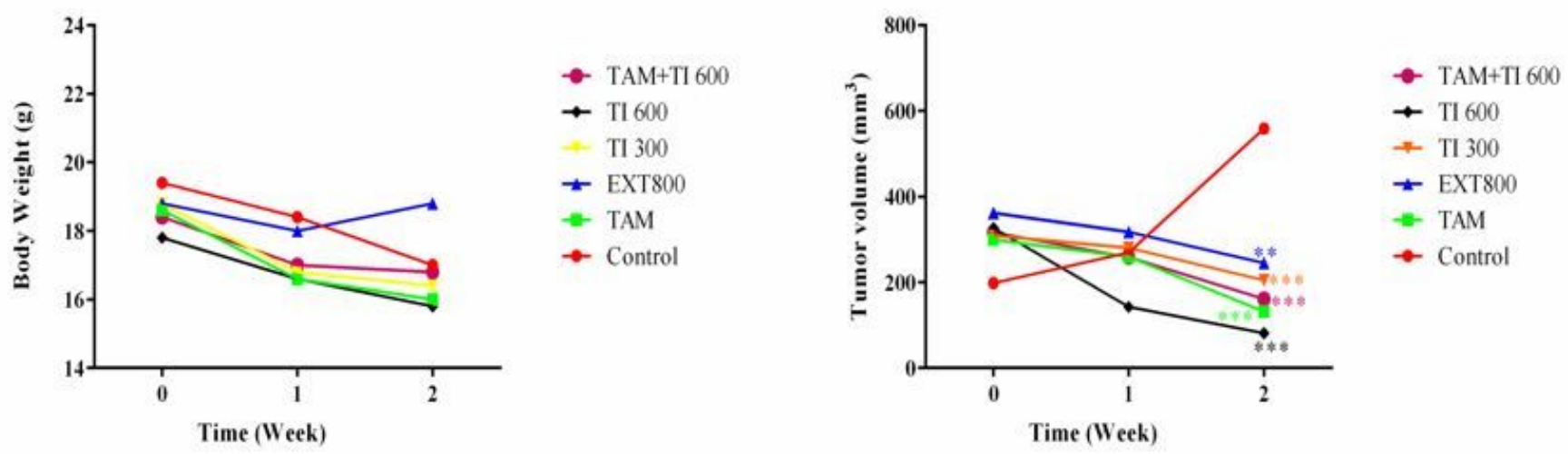

C

- TAM+TI 600

$\rightarrow$ Tl 600

TI 300

- EXT800

- TAM

$\rightarrow$ Control

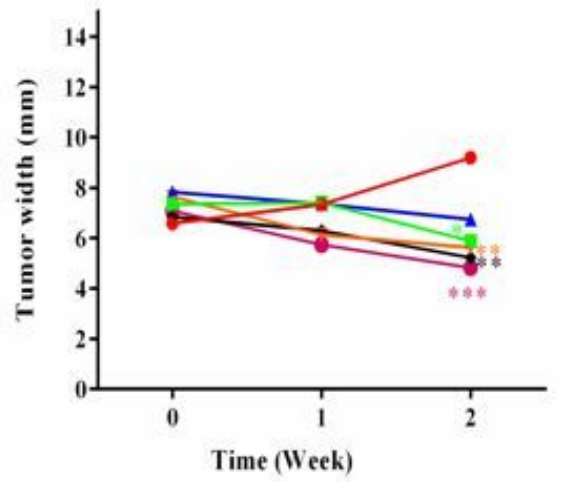

- TAM+TI 600

$\leftarrow$ TI 600

$\rightarrow$ Tl 300

— EXT800

-1- TAM

- Control
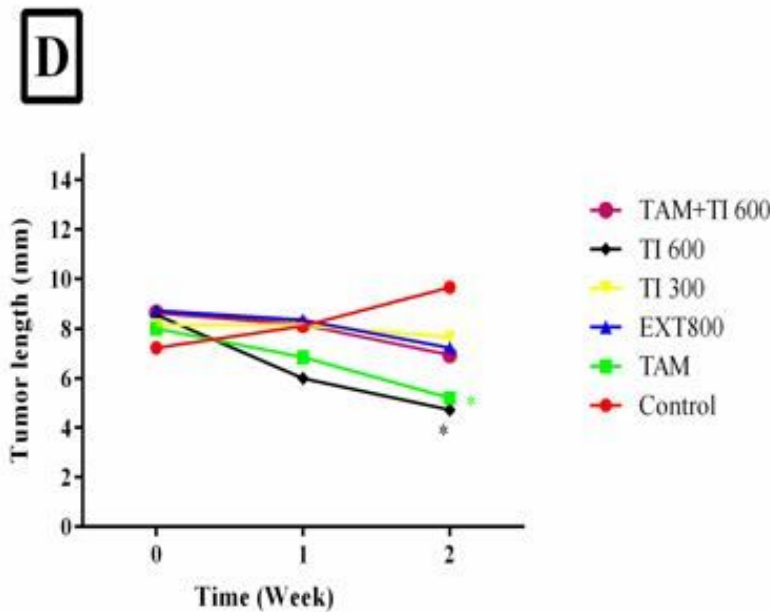

E

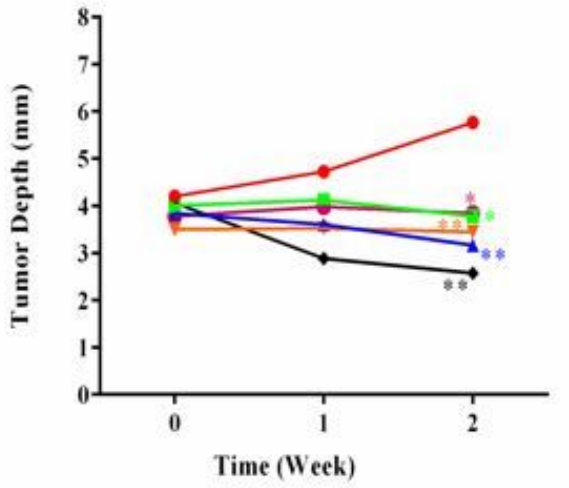

- TAM+TI 600

$\rightarrow$ TI 600

* Tl 300

* $\quad \mathrm{P}<0.05$

- EXT800

- TAM

$* * \mathrm{P}<0.01$

$\rightarrow$ Control

$* * * \mathrm{P}<0.001$

Figure 8

Evaluation of body weight and tumor characteristics in experimental groups. A-E: Control: breast cancer control group; TAM: breast cancer tamoxifen $10 \mu \mathrm{mol}$ group; EXT800: breast cancer extract $800 \mu \mathrm{gr} / \mathrm{ml}$ group; TI300: breast cancer trypsin inhibitor $300 \mu \mathrm{gr} / \mathrm{ml}$ group; TI600: breast cancer trypsin inhibitor 600 $\mu \mathrm{gr} / \mathrm{ml}$ group; TAM+TI600: breast cancer tamoxifen $10 \mu \mathrm{mol}+$ trypsin inhibitor $600 \mu \mathrm{gr} / \mathrm{ml}$. A) *: All treated groups vs. Con at P<0.05; B) **, ***: TAM, EXT800, TI300, TI600 and TAM+TI600 groups vs. Con at 
$\mathrm{P}<0.01$ and $\mathrm{P}<0.001$, respectively; $\mathrm{C})$ * **, $* \star *$ : TAM, TI300, TI600 and TAM+TI600 vs. Con at $\mathrm{P}<0.05$, $\mathrm{P}<0.01$ and $\mathrm{P}<0.001$, respectively; $\mathrm{D}) *$ : TAM and TI600 vs. Con at $\mathrm{P}<0.05 ; \mathrm{E}) *$, $* *$, ***: TAM, TI300, TI600 and TAM+TI600 vs. Con at $P<0.05, P<0.01$ and $P<0.001$, respectively. Data are presented as Mean $\pm S D$.

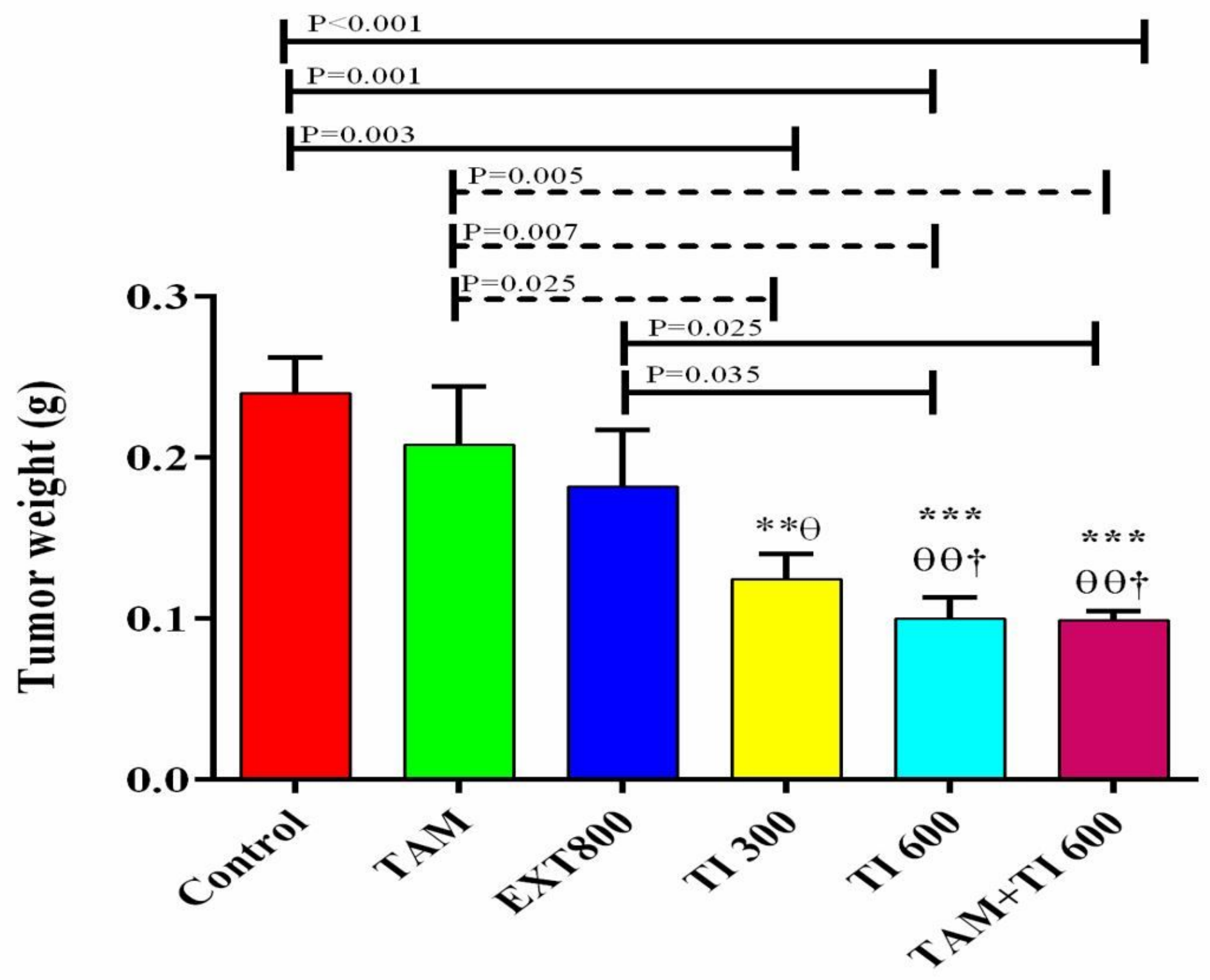

Figure 9

Evaluation of tumor weight in experimental groups at the end of the interventions. Control: breast cancer control group; TAM: breast cancer tamoxifen $10 \mu \mathrm{mol}$ group; EXT800: breast cancer extract $800 \mu \mathrm{gr} / \mathrm{ml}$ group; TI300: breast cancer trypsin inhibitor $300 \mu \mathrm{gr} / \mathrm{ml}$ group; T1600: breast cancer trypsin inhibitor 600 $\mu \mathrm{gr} / \mathrm{ml}$ group; TAM+TI600: breast cancer tamoxifen $10 \mu \mathrm{mol}+$ trypsin inhibitor $600 \mu \mathrm{gr} / \mathrm{ml}$. **: All treated

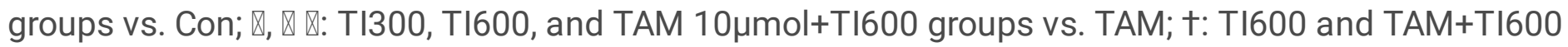
groups vs. EXT800. Data are presented as Mean \pm SD. 

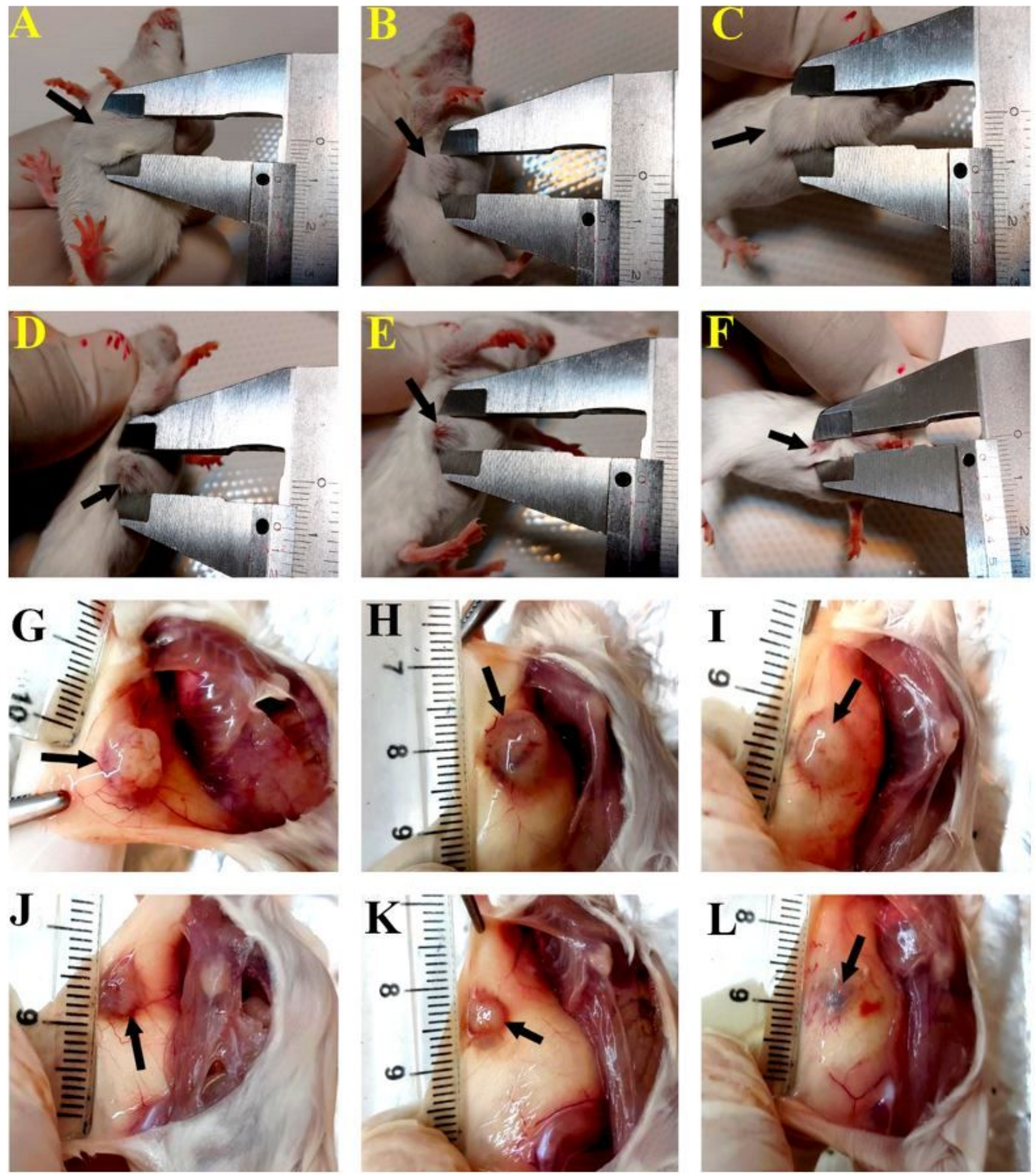

Figure 10

Induced breast tumor in mice

\section{Supplementary Files}

This is a list of supplementary files associated with this preprint. Click to download. 
- supp1.docx

Page 26/26 